\title{
Industrial Practice of Sewage Sludge Pump directly into Cement Kiln
}

\author{
Liu HaiBing ${ }^{1, a}$ and Gu Jun ${ }^{1, b}$ Han $i^{1, c}$ Wang Ping ${ }^{1, d}$ \\ Zhang Nan ${ }^{1, \text { e }}$ Cai WenTao ${ }^{1, f}$
}

1 Beijing Building Materials Academy of Science Research/State Key Laboratory of Solid Waste

\author{
Reuse for Building Material , Beijing 100041, China \\ 2 Beijing Taihangqianjing cement CO., LTD. Beijing 102471, China \\ ahblff@126.com, bgujun@bbma.com., chanli-007@163.com, \\ dwp007080@sina.com, thqjzlb@163.com, ${ }^{e}$ wentao175@qq.com
}

\begin{abstract}
Keywords: sewage sludge; cement co-process; alternative fuel
Abstract. The 150 tpd facilities of sewage sludge pump directly into precalciners was set up in cement plant of 3200 tpd clinker production. The experiment was performed at the sludge feed rate of $4 \mathrm{t} / \mathrm{h}$, $6 \mathrm{t} / \mathrm{h}$ and without sludge. It was showed from that the use of sludge as alternative fuel did not affect clinker quality negatively. The initial and final setting times of cement clinker were longer than when sludge was not co-disposed, but they remain within the standard range. With the increase of sludge volume from coal consumption increased, the yield decreased. Sludge as an alternative fuel, not only can reduce ammonia consumption and to help reduce nitrogen oxide emissions. Finally, the run data find that if the moisture content of the sludge to reduce, the volume of sludge can increase.
\end{abstract}

\section{Introduction}

Sewage sludge is generated primarily by municipal wastewater treatment plants (WWTPs). It has increased substantially in recent years because of an increase in the number and size of urban communities and as well as in the amount of wastewater discharged by industrial processes[1].. The most common treatment options for sludge include landfill, compost and incineration[2].These treatment technologies play an important role in the practical application, but they have some drawbacks. How to treat sludge in a safe and effective way has become a major problem in the process of urban development.

Waste co-processing has been practiced for more than 20 years, especially in developed countries/regions such as Europe, Japan, the United States, and Canada.Cement kiln co-processing of municipal wastes provides high temperatures, long residence time, surplus oxygen, good mixing conditions and an alkaline environment, as well as efficient recovery of any energy and raw material substitutes in the waste[3,4].

Relying on the state-of-the-art cement production lines and above rule,Beijing Build Material Group (BBMG) has carried out several engineering practices in Beijing,Tianjing and Heibei since 2006. At present, BBMG has developed ways of sludge incineration directly in precalcine. This paper gives a brief introduction of the processes and technical characteristics of Beijing Taihangqianjing cement plant.

\section{Material and Methods}

Composition and characteristics of sewage sludge

The wet sewage sludge was from a waste water facility of Beijing Xiaohongmen district. The proximate and ultimate analysis of sewage sludge was Table 1. 
Table 1. sewage sludge proximate analysis

\begin{tabular}{|l|l|l|l|l|l|l|}
\hline $\begin{array}{l}\text { proximate } \\
\text { analysis }\end{array}$ & $\begin{array}{l}\text { Water } \\
\text { (wt-\%, raw) }\end{array}$ & Ash (wt-\%, & Volatiles (wt-\%) & Fixed carbon (wt-\%) & $\begin{array}{l}\text { Lower heating value } \\
(\mathrm{kJ} / \mathrm{kg})\end{array}$ \\
\cline { 2 - 7 } & 80 & 9.1 & 10.1 & 0.8 & 2429 & $\mathrm{~S}$ \\
\hline $\begin{array}{l}\text { Ultimate } \\
\text { analysis } \\
(\text { wt-\% })\end{array}$ & $\mathrm{C}$ & $\mathrm{H}$ & $\mathrm{O}$ & $\mathrm{N}$ & $\mathrm{Cl}$ \\
\cline { 2 - 7 } & 3.0 & 1.35 & 2.4 & 3.1 & 0.6 & 0.45 \\
\hline
\end{tabular}

Table 2 sludge ash composition analysis

\begin{tabular}{|c|c|c|c|c|c|c|c|c|c|c|c|c|c|c|c|c|}
\hline $\mathrm{Na}$ & $\mathrm{Mg}$ & $\mathrm{Al}$ & $\mathrm{Si}$ & $\mathrm{P}$ & $\mathrm{K}$ & $\mathrm{Ca}$ & $\mathrm{Ti}$ & $\mathrm{Cr}$ & $\mathrm{Mn}$ & $\mathrm{Fe}$ & $\mathrm{Cu}$ & $\mathrm{Zn}$ & $\mathrm{Sr}$ & $\mathrm{Zr}$ & $\mathrm{Ba}$ & $\mathrm{Zn}$ \\
\hline 0.97 & 2.16 & 28.14 & 24.86 & 14.08 & 1.325 & 6.80 & 0.73 & 0.06 & 0.05 & 12.32 & 0.05 & 0.25 & 0.04 & 0.02 & 0.32 & 0.02 \\
\hline
\end{tabular}

Cement kiln co-processing sludge setup

The dewatered sludge was obtained from the municipal wastewater treatment plants around the Yue Bao cement plant. The moisture content of this sludge was approximately about $80 \%$. Given the high moisture content and low calorific value of dewatered sludge, the cement plant built sludge tank with a carriage. And it select to fed directly to the bottom of the calciner through high pressure pumps. Cement Plant is a five-stage calciner kiln, equipped with a TFD in-line calciner reconstructed the $3200 \mathrm{t} / \mathrm{d}$ clinker production and buit a $150 \mathrm{t} / \mathrm{d}$ sludge co-processing line.

The process flow was as follows figures 1: wet sludge from sewage treatment plant (water content of about $80 \%$ ) was transported to warehouses in cement plant and then fed directly to the sludge spray nozzle install bottom of the calciner through high pressure pumps.

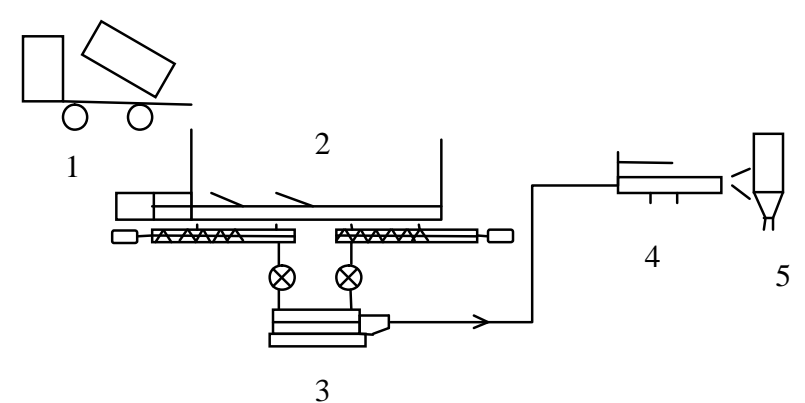

Figures 1. Schematic presentation of the cement kiln co-processing 1: truck; 2:sludge tank;3:pump;4:sludge spray gun;5: calciner

\section{Results and Discussion}

Effect of sludge feed rate on calciner quality

Cement plants were usually concerned with the influence on product quality and fuel consumption when sludge was used to replace or increase coal in clinker production. Thus, the physical properties and mineral composition of the cement clinkers produced with and without sludge were analyzed and compared in the current study to evaluate the effect of sludge addition. As listed in Tables 3, the qualities of the two types of cement were almost similar. Moreover, they both meet China's standard for common Portland cement (GB175-2007). Therefore, the use of sludge as alternative fuel did not affect clinker quality negatively. The initial and final setting times of cement clinker were longer than when sludge was not co-disposed, but they remain within the standard range. Some chemical components from the sludge, including $\mathrm{Zn}, \mathrm{P}$, and $\mathrm{Pb}$ compounds, can delay the clinker hydration reaction [5]; nonetheless, the proper delay of cement setting time did not affect the performance of the cement. On the contrary, this delay was conducive to construction. 
Table 3 The chemical composition (wt.\%) of cement produced with and without sludge.

\begin{tabular}{|l|c|c|l|l|l|l|l|l|l|}
\hline sample & $\mathrm{SiO} 2$ & $\mathrm{Al} 2 \mathrm{O} 3$ & $\mathrm{Fe} 2 \mathrm{O} 3$ & $\mathrm{CaO}$ & $\mathrm{MgO}$ & $\mathrm{f}-\mathrm{CaO}$ & $\mathrm{R} 2 \mathrm{O}$ & $\mathrm{SO}$ & $\mathrm{Cl}^{-}$ \\
\hline With sludge & 21.07 & 5.55 & 3.49 & 63.5 & 4.3 & 1.52 & 0.49 & 0.57 & 0.19 \\
\hline Without sludge & 21.10 & 5.09 & 3.26 & 62.8 & 4.2 & 1.48 & 0.51 & 0.54 & 0.16 \\
\hline
\end{tabular}

Effect of sludge feed rate on kiln operation

In this plant, the wet sludge feed point was bottom of calciner. As displayed in Fig. 2, feed rate was also a key factor on sludge combustion. As the gas temperature and speed were help to spread and burning in it. The moisture content has a negative effect on the combustion process associated with the heat loss due to water evaporation $(2,257 \mathrm{~kJ} / \mathrm{kg}$ water), which reduces the net amount of energy released during sludge combustion [4]. This situation was supported with the results obtained in this study as can be seen in Table 4.As table. 3 illustrates, with the increase of sludge volume from $0 \mathrm{t} / \mathrm{h}$ to $6 \mathrm{t} \cdot / \mathrm{h}$, coal consumption increased, the yield decreased

Table 4 The cement kiln run with and without sludge.

\begin{tabular}{|c|c|l|l|}
\hline sample & \multicolumn{1}{|c|}{$\begin{array}{c}\text { feed rate of sludge } \\
\mathrm{t} / \mathrm{h}\end{array}$} & $\begin{array}{c}\text { coal consumption } \\
\mathrm{t} / \mathrm{h}\end{array}$ & $\begin{array}{c}\text { raw material } \\
\mathrm{t} / \mathrm{h}\end{array}$ \\
\hline 1 & 0 & 16.2 & 201 \\
\hline 2 & 4 & 17.1 & 196 \\
\hline 3 & 6 & 18.3 & 190 \\
\hline
\end{tabular}

Effect of sludge feed rate on gas emission

When the sludge was carried in the calciner, the outlet concentration of $\mathrm{NO}_{\mathrm{X}}$ was decreased, and ammonia about SNCR also remarkable mass drops. The basic principle was to utilize the naturally occurring ammonia content of dewatered biosolids as the reagent[6]. The sludge displays a high volatile yield. In the early stages of combustion, many volatiles were released to produce numerous reducing species $\left(\mathrm{HCN}, \mathrm{NH}_{3}, \mathrm{CO}\right.$, and $\left.\mathrm{CmHn}\right)$ under hypoxic conditions [7,8].

\section{Conclusions and suggestion}

This paper reviews practices co-processing of sewage sludge in cement plants. The result suggest that the cement kiln can be used for both wet sludge co-processing for environment and natural fossil fuel saving. Although quality standards, but because of high moisture content, cement kiln production decreased and coal consumption increased. The initial and final setting times of cement clinker are longer than when sludge is not co-disposed sludge. Secondly, Sludge as an alternative fuel, not only can reduce ammonia consumption and to help reduce nitrogen oxide emissions. Finally, the run find that if the moisture content of the sludge to reduce, the volume of sludge can increase.

\section{Acknowledgments}

This work was supported by the National Science \& Technology Pillar Program during the 12th Five-year Plan Period (Grant 2012BAC15B002) and Beijing Taihangqianjing cement CO., LTD.

\section{References}

[1] Wu Shumin,Yang Yibo,Peng Xin. Research progress of chipping concrete,J. Building technology $\square 2010(1) \square 67-70$.

[2] Werther J.O gada T. Sewage sludge conmbustion, J. Prog Energy Combust Sci,1999,25:55-116.

[3] Japan Sewage Works Association. The status of the sludge treatment[ EB /OL] . http: /

/www.jswa. jp /05arekore /date - room/05/ r iyou /data htm ,1 2007- 07- 01.

[4] Alfonso Aranda-Usón .Characterization and Environmental Analysis of Sewage Sludge as Secondary Fuel for Cement Manufacturing ,J. Chemical Engineering Transactions,. VOL. 29, 2012

[5] G.X. Liu, Y.Q. Li, F. Zeng, W. Fan, L.X. Guo, Experimental study on sludge disposal of wastewater treatment plants utilizing cement kilns, J. Changchun Univ. Sci. Technol.(Nat. Sci. Ed.) 33

(2010) 134- 135 (in Chinese). 
[6] Biggs, H.O., Plant Manager, Mitsubishi Cement Corporation. Biosolids Injection Technology: An Innovation in Cement Kiln NOx Control. (no date). Received during December 1999 trip report.

[7] J.C. Yang, R. Sun, S.Z. Sun, N.B. Zhao, N. Hao, H. Chen, Y. Wang, H.R. Guo, J.Q. Meng, Experimental study on $\mathrm{NO}_{\mathrm{X}}$ reduction from staging combustion of high volatile pulverized coals. Part 1. Air staging, Fuel Process. Technol. 126 (2014) 266- 275.

[8] B. Coda, F. Kluger, D. Förtsch, H. Spliethoff, K.R.G. Hein, L. Tognotti, Coal- nitrogen release and $\mathrm{NO}_{\mathrm{X}}$ evolution in air-staged combustion, Energy Fuel 12 (1998) 1322- 1327. 